\title{
Islamic and Conventional Equity Fund Rating Performance withalReturn, Sharpe, Modified Snail Trail, and Morningstar Rating Groundwork
}

\author{
A. F. Hartono, S. Soekarno, and S. M. Damayanti
}

\begin{abstract}
This research aims to assess the performance of equity fund in Indonesia, Islamic and Conventional, whether they can outperform the market. The samples used in this research are 36 equity funds which have been established prior to January 2008. The performance measurement methods are rating based on return, Sharpe index, Modified Snail Trail, and Morningstar. This research finds that the performance of Islamic equity fund does not differ significantly compared to market and conventional equity fund based on return and Sharpe Index. The finding in high rating portfolio is quite obvious, high return and Sharpe Index rating portfolios produce the highest expected return of $1.09 \%$ in 5 years. Meanwhile, modified snail trail method shows 1\% expected return, and the lastly, Morningstar rating indicates $0.64 \%$ return. These portfolios, except for Morningstar rating, outperform to benchmark portfolios namely, equally weighted portfolio and minimizing risk portfolio in all of three categories.
\end{abstract}

Index Terms - Conventional equity fund, islamic equity fund, modified snail trail, morningstar rating, sharpe index.

\section{INTRODUCTION}

According to data provided by BAPEPAM, mutual fund Indonesia mostly concentrated on certain conventional types, such as; equity, protected, fixed income, and discretionary mutual funds which together accounts for $88,90 \%$ of overall net asset value in 2012. Islamic mutual fund, on the other hands, is less demanded, and takes account only for $2.87 \%$ of the whole net asset value in 2012 .

This fact is ironic, remembering Indonesia is country with one of the largest Muslim society with large potentials on development of Islamic industry. According to Global Islamic Financial Report in 2011; Indonesia was on forth position with largest potential of Islamic industry, after Iran, Malaysia, and Saudi Arabia [1].

With that potential on Islamic mutual funds development, the less concerned on Islamic mutual fund can be caused by ignorance of Islamic mutual fund performance and the common paradigm that Islamic mutual fund will give lowers return than conventional mutual fund. Therefore, a research to compare Islamic and conventional equity mutual fund to market indexes is required.

Manuscript received April 12, 2013, revised June 10, 2013.

The authors Are with the School of Business and Management, Bandung Institute of Technology, J1. Ganesha 10, Bandung, 40132, West Java, Indonesia (e-mail: antonia.febe@sbm-itb.ac.id, subiakto@sbm-itb.ac.id sylvianamaya@sbm-itb.ac.id).

\section{LITERATURE REVIEW}

\section{A. Mutual Fund}

According to Capital Market Laws number 8 in 1995, chapter 1 , verse 27 , mutual fund is a vessel for containing funds from public investors to invest in portfolio securities by investment manager. Mutual fund is classified as openend fund which issue the shares at its net asset value with charges on both purchases and redemptions [2].

\section{B. Islamic Mutual Fund}

According to Fatwa which issued by National Sharia Board $(2012 ; 3)$ Islamic mutual fund is mutual fund which operated according to provisions and Islamises principles, whether in form of investor as the fund owner (sahib al-mal / Rabb al Mal) with investment manager as the representative of sahib al-mal or investment manager with investment user [3].

The operational mechanisms of sharia mutual fund consist of wakalah and mudharabah. Wakalah is authority delegation from sahib al-mal to investment manager for representable matter [4]

1) Difference between izslamic and conventional mutual fund

The fundamental difference between Islamic and conventional mutual fund is when selecting investment for the portfolio, conventional mutual fund can freely choose between debt-based investment and profit-based investment, and invest in all available industries [5]. However, onIslamic mutual fund, the asset allocation must filter the asset which meets the criteria of sharia guidelines. Sharia guidelines forbid speculations that contain fraud (gharar) such as; Najsy, that is fake offering, Bai al-Ma'dum, which is sells not owned items or known as short selling, insider trading which is promulgating misleading information or use inside information to gain a prohibited transaction, and investing in high leveraged companies, with debt to capital ratio higher than $82 \%$ [6].

\section{Mutual Fund Performance Measurement}

\section{1) Return}

This research will assess the return performance of Islamic compared to conventional equity fund and the market. Thehigher the return of equity fund compared to the market return, the better performance of that equity fund. The equity fund return is computed from Net Asset Value from each sub period for each equity fund. See Fig. 1

$$
r_{d=} \frac{N A V_{1}-N A V_{0}}{N A V_{0}}
$$


$\underline{r}_{d}=$ Average return for certain period

$N A V_{1}=$ Net Asset Value this month

$N A V_{0}=$ Net Asset Value the month before

\section{2) Sharpe}

This index was developed by William F. Sharpe is used to measure how much return is got in exchange of certain amount of risk. Sharpe Index is computed exerting this formula [7]:

$$
S_{R D}=\frac{r_{d}-r_{f}}{\sigma}
$$

$S_{\mathrm{R}}=$ Sharpe Index

$r_{d}=$ Mutual fund return for certain sub-period

$\sigma=$ Standard deviation of mutual fund for certain subperiod

$r_{f}=$ Risk free rate for certain sub-period.

Higher geometric means of Sharpe index means higher excess return relatives to $1 \%$ of risk, therefore it shows better performance.

\section{3) Snail trail method}

This method will illustrated graphically the relative return and relative risk of each mutual fund for each month then associate it with the return and the risk the next period. Relative return is calculated by subtracting the return for certain period with the median for the same period of all samples.

To measure risk, there are several alternatives. The most common accepted measure of risk is standard deviation of return [8]. Relative risk is measured by subtracting the risk for certain period with median of risk derived from all samples on the same period.

Relative return is plotted on vertical axis whereas relative risk is plotted on the horizontal axis. The first point on riskreturn graph is plotted as usual. The points of the period then rolled forward by one month risk-return pair. Those points plotted on the same graph; therefore the pattern is traced dynamically in risk-adjusting space.

The desirable above median return appear above horizontal relative return line, and less desirable belowmedian return appear below the horizontal line. The desirable below median volatility appear on the left of diagram, and less demanded above median volatility appear on the right of diagram. The most desirable region is on the first quadrant, which is located on the top left, while the least desirable isolated on the third quadrant [9].

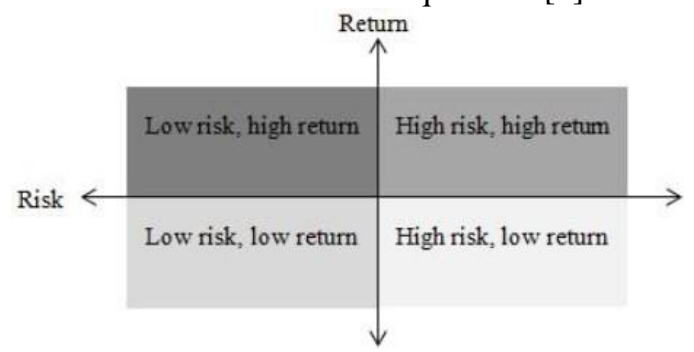

Fig. 1.Quadrant of snail trail is explained within this picture; formula 1 . quadrant of snail trail

\section{4) Morningstar rating}

The original Morningstar Rating was introduced in 1985 and was used to help investor to choose one or few fund among large choices of asset class investment available. Morningstar assigns rating based on comparison of all fund within specific Morningstar category rather than broad asset class as the emphasized is not stand alone investment, but funds as portfolio component and fund with particular rating can be substituted with one another in construction of diversified portfolio[10].

To give rating based on Morningstar computation, these five steps should be followed:

1) Figure Morningstar Risk-Adjusted Return or MRAR (2) and Morningstar Return or MRAR( 0$)$ for 3 and 5 years are the basic things to do. There are four steps to calculates MRAR(2) for 3 years;

- Calculate total monthly return for the fundusingMorningstar formulation, fund total return for given month is supposed to be derived from

$$
T R_{t}=\left[\frac{P_{e}}{P_{b}} \prod_{t=1}^{36}\left(1+\frac{D_{i}}{P_{i}}\right)\right]-1
$$

$T R_{\mathrm{t}}=$ Total return for the fund for month $t$

$P_{\mathrm{e}}=$ End of month NAV per share

$P_{\mathrm{b}}=$ Beginning of month NAV per share

$D_{\mathrm{i}}=$ Pershare distribution at time $i$

$P_{\mathrm{i}}=$ Reinvestment NAV per share at time $i$

However, the distribution is directly reflected on NAV, instead of distributed to equity fund holder. Therefore the total return is computed using formula 1 .

The cumulativetotal return is acquired from;

$$
T R_{C}=\prod_{t=1}^{36}\left(1+T R_{t}\right)-1
$$

$T R_{\mathrm{C}}=$ Cumulative total return for the fund

$T R_{\mathrm{t}}=$ Total Return for the fund month $t$

- Adjust the monthly total return for sales loads to compute load adjusted return. The load-adjusted return is calculated as;

$$
L R_{C}=\left(1+T R_{C}\right) \times(1-S) \times(1-R)-1
$$

where

$L R_{\mathrm{c}}=$ Cumulative load-adjusted return for 3 years

$T R_{\mathrm{c}}=$ Cumulative total return for 3 years

$F=$ Maximum front load or subscription fee, expressed as decimal

$R=$ Redemption fee, expressed as decimal

Monthly adjustment factor for loads, $a$, is determined by;

$$
a=\left(\frac{1+L R_{C}}{1+T R_{C}}\right)^{\frac{1}{36}}
$$

Then, the monthly total return is adjusted with this factor,

$$
L R_{t}=a \times\left(1+T R_{t}\right)-1
$$

where

$L R_{\mathrm{t}}=$ Load-adjusted total return for month $t$

$T R_{\mathrm{t}}=$ Total return for month $t$

- Figure Morningstar Return or MRAR (0) by collect monthly total return for the appropriate risk free rate. For each historical month, the fund's geometric excess return over risk free rate is computed from;

$$
E R_{t}=\left\lfloor\frac{1+L R_{t}}{1+R F_{t}}\right\rfloor-1
$$

where

$E R_{t}=$ Geometric excess return for the fund for the month $t$ $L R_{t}=$ Load adjusted return for the fund for month $t$ 
$R F_{t}=$ Total return for the risk free rate for month $\mathrm{t}$, figured by using formula 3,10

The annualized geometric mean of these excess return is known as Morningstar Return or $\operatorname{MRAR}(0)$.

$$
\operatorname{MRAR}(0)=\left\lfloor\prod_{t=1}^{36}\left(1+E R_{t}\right)\right\rfloor^{\frac{12}{36}}-1
$$

- Adjusted MRAR(0) to get MRAR(2)

$$
\operatorname{MRAR}(2)=\left\lfloor\frac{1}{36} \sum_{t=1}^{36}\left(1+E R_{t}\right)^{-2}\right\rfloor^{\frac{-12}{2}}-1
$$

The section inside the brackets determines the investor average utility from this fund's monthly excess return over 36 months. Then, that utility level is converted to a return by taking it to the power of $-1 / 2$ and annualizes the result by taking the power of 12 .

To calculate the 5 years $\operatorname{MRAR}(2)$ and $\operatorname{MRAR}(0)$, repeat the steps a to $d$ and substitute 36 with 60 .

- Then, all funds in the category are sorted by rank MRAR in descending order.

- The rating given is based on the rank of MRAR is based on these rules stated in Table I.

TABLE I: RULES FOR MORNINGSTAR RATING

\begin{tabular}{|c|c|c|}
\hline Score & Percent & Word Label \\
\hline 5 & Top $10 \%$ & High \\
\hline 4 & Next $22,5 \%$ & Above Average \\
\hline 3 & Next $35 \%$ & Average \\
\hline 2 & Next $22,5 \%$ & Below Average \\
\hline 1 & Bottom $10 \%$ & Low \\
\hline
\end{tabular}

2) In order to compute Morningstar Risk from subtracting Morningstar Risk-Adjusted Return from Morningstar Return and rank the Morningstar Risk with the same rule of Morningstar Rating. Morningstar Risk is useful to determine the more preferred equity fund when the funds have same rating, and similar $\operatorname{MRAR}(2)$ but different level of risk.

$$
\text { Morningstar Risk }=\operatorname{MRAR}(0)-\operatorname{MRAR}(2)
$$

3) To calculate the overall Morningstar Rating by using weighting average of rating for 3 and 5 years Morningstar Risk Adjusted Return.

$$
M R A R_{\text {overall }}=\operatorname{MRAR}(2)_{3} \times 40 \%+\operatorname{MRAR}(2)_{5} \times 60 \%
$$

\section{DATA AND METHODOLOGY}

\section{A. Data Collection Method}

For computation methods to evaluate the mutual fund performance, return, Sharpe, Snail Trail and Morningstar rating will be used. Data used for computation are:

- Monthly Net Asset Value for each mutual fund from January 2008 until December 2012

- IHSG (IndeksHargaSahamGabungan or Jakarta Composite Index) and JII (Jakarta Islamic Index) as the market representation

Interest rate of SBI will be used as risk free rate from
January 2008 until December 2012. The SBI for 1 month period is primary used for this research. However, as SBI for 1 month period was discontinued in June 2011, the month after will use SBI for 3 month period.

The data of fee rate for each equity fund is derived from each prospectus and fund fact sheet. If any mutual fund does not publish the mutual fund online, the mode of the rate will be used. If mutual funds have multilevel of fee, the maximum fee will be used.

\section{B. Data Processing}

\section{1) Computing return and sharpe index}

The return and the Sharpe Index are computed for each equity fund, for each year using formula 1. Both IHSG and JII are computed the return and the Sharpe Index as well. The formula used for IHSG and JII are quite similar with formula 1 .

In order to make general statement of equity fund performance for the whole research period, geometric mean are used to compute the average mean of certain equity fund.

2) Use statistical test to test significance difference of return and risk adjusted return

To assess whether there is significance difference between return of Islamic and conventional equity fund, Islamic equity fund with market (JII) and conventional equity fund with market (IHSG), one way - ANOVA test will be conducted with hypothesis of [11].

Ho: $\mu_{1}=\mu_{2}=\mu_{3}=\mu_{4}=\ldots=\mu_{n}$

Ha: not all means are equal

Instead of using data analysis by Microsoft Excel, this research conducts the ANOVA test manually in order to use geometric mean as the average method instead of arithmetic mean. This method is chosen to present consistency between methods used. The decision to reject the null hypothesis $\left(\mathrm{H}_{\mathrm{o}}\right)$ is when the F-test computed is greater than upper tail critical value denotes with c. For this research the level of significance used is $5 \%$.

TABLE II: QUADRANT MULTIPLIER FOR MODIFIED SNAIL TRAIL

\begin{tabular}{|c|c|c|}
\hline Quadrant & Word Label & Multiplier \\
\hline Low risk, high return & Favourable performance & +1 \\
\hline High risk, high return & Average performance & +0.5 \\
\hline Low risk, low return & Average performance & -1 \\
\hline High risk, low return & Unfavourable performance & -2 \\
\hline
\end{tabular}

3) Mapping the snail trail and computing the modified snail trail score

Before mapping the snail trail, firstly, relative risk and return need to be computed. Afterward, each pairs of relative risk and return is plotted on the quadrant, with relative risk on $\mathrm{x}$-axis and relative return on $\mathrm{y}$-axis.

Based on the desired quadrant, the modified snail trail score is computed. Firstly, it computes distance from the certain point to $(0,0)$ by using this formula;

$$
\text { Relative distance }=\sqrt{\begin{array}{l}
\text { (relative } \\
\text { return })
\end{array}+\begin{array}{c}
\left(\text { relative }{ }^{2}\right. \\
\text { risk })
\end{array}}
$$


Afterward the relative distance is multiplied by quadrant multiplier, which are

The number for quadrant multiplier is based on the theory of behavioral finance, with equity premium puzzles anomalies that stated tendency for investor to overly preoccupied by negative effect of losses in comparison to equivalent amount of gains. The relative distance which has been multiplied by quadrant multiplier is called modified snail trail score, which computed with this formula

$$
\underset{\text { trail score }}{\text { Modified snail }}=\begin{aligned}
& \text { Relative } \\
& \text { distance }
\end{aligned} \times \begin{aligned}
& \text { Quadrant } \\
& \text { multiplier }
\end{aligned}
$$

Subsequently, each period of modified snail trail score is averaged using geometric mean,

$$
\begin{gathered}
\text { Modified snail } \\
\text { trail score overall }
\end{gathered}=\left(\prod_{t=1}^{N} \begin{array}{c}
\text { modified snail } \\
\text { trail score }
\end{array}+1\right)-1(15)
$$

4) Rating for return, sharpe index, and modified snail trail

To assess the rating for the return, Sharpe Index, and modified snail trail, the data for each method is sorted descending, The rating rule is based on the Morningstar Rating rules specified in Table I.

\section{5) Computes morningstar rating}

The Morningstar rating can be computed computes MRAR(2) using formula 2.5 until 2.13, sorted in descending order, and assign the rating based on the ratings rules that specified in Table I.

\section{6) High rating equity fund portfolios}

To assess which rating gives the best prediction of return and risk performance, portfolio based on the high rating equity fund for each method will be prepared. High rating equity fund is defined with equity fund which is granted with 4 or 5 star rating. As each method gives different result of high rating equity fund, the high rating equity fund portfolios will consist of different equity funds for each method.

The portfolio performance will be assessed with back testing method. Based on the weight computed, the return of the portfolio for 5 years period will be computed.These portfolios will use buy and hold method for the period of 5 years.

For the benchmark of high rating equity fund portfolios, this research will establish the optimal portfolio of conventional equity fund portfolio, Islamic equity fund portfolio, and hybrid equity fund portfolio. Optimal portfolio is defined as gives highest return for same risk, or produces lowest return for certain level of risk. The asset contained on the portfolio will be based on purpose of the portfolio. Four alternatives are given, which are equal weighted, maximizing the return, minimizing the risk, or maximizing the Sharpe ratio of the whole portfolio. To search for the weight of each equity fund, solver in Microsoft Excel will be used.

\section{EMPIRICAL RESULT}

\section{A. Return}

Even though the return of the samples are seems to be different, based on the ANOVA test with the 5\% level of significance, the statistical test says different way.

After all, with the result of the statistical test, it can be stated that the performance of Islamic equity fund is statically equal to the performance of conventional equity fund. Moreover, both of them do not outperform or underperform the market.

\section{B. Shape Index}

Build on the result of Sharpe Index which shown on the table 2 in the appendixes shows that there is slightly different on risk adjusted return of the equity fund. Therefore, the rating granted is different to each other. However, after conducting ANOVA test with 5\% level of significance, this research stated that there are no significance differences on risk adjusted return performance of Islamic equity fund compared to conventional equity fund, Islamic equity fund compared to the market, and conventional equity fund compared to the market.

\section{Modified Snail Trail}

Based on the historical relative return and risk that mapped in snail trail quadrant it is found that 11 equity funds have tendency to have high risk with volatile return. Those equity funds are Bahana Dana Prima, Batavia Dana Saham, Batavia Dana Saham Optimal, BNI ReksadanaBerkembang, BNP Paribas Ekuitas, GMT Dana Ekuitas, Grow-2-Prosper, PratamaSaham, Reksa Dana BNP Paribas Infrastruktur Plus, Reksa Dana DanaEkuitas Prima, Reksa Dana MandiriInvestaAtraktif, Reksadana Dana PratamaEkuitas, Syailendra Equity Opportunity, Trim Kapital, Reksa Dana Syariah BNP Paribas PesonaAmanah, CIMB Principal Islamic Equity Growth Syariah. Those equity funds' performances are transmigrating from high risk low return to high risk high return and vice versa. The rest is belongs to relatively low risk category with volatile return, which transmigrate from low to high return and vice versa.

After assessing the tendency, by using the modified snail trail method, the performance of relative risk and return of equity fund can be quantified, ordered, and assigned with ratings.

\section{Rating's result}

The equity funds which gain 5 stars are Panin Dana Maksima, Grow-2-prosper, and Syailendra Equity Opportunity fund. On the other hand, equity funds with gain 4 stars are Batavia Dana Saham, BNP Paribas Pesona, GMT Dana Ekuitas, Manulife SahamAndalan, Reksa Dana NISPIndeksSahamProgresif, ReksaDana Schroder Dana Istimawa, RencanaCerdas, Schoder Dana Prestasi Plus, and Reksa Dana ShariahBNP Paribas PesonaAmanah. From 12 of the best equity fund, only one of them belongs to Islamic equity fund and the rest are belongs to conventional equity fund.

For the rating based on the risk adjusted return, the result is exactly similar with rating based on the return. Therefore, it can be stated that the equity fund has directly proportional risk adjusted return.

The result of the modified snail trail rating can be seen on the Table III and continued to Table IV. Equity funds which 
granted with 5 stars are Panin Dana Maksima, Reksa Dana NISP IndeksSahamProgresif, Reksa Dana Schroder Dana Istimewa. Conversely, equity funds which are granted with 4 stars are Batavia Dana Saham, BNI Paribas Pesona, GMT Dana Ekuitas, Grow-2-Prosper, Manulife Dana Saham, Reksa Dana SimasDanamasSaham, Reksa Dana DanaEkuitasAndalan, RencanaCerdas, and Schroder Dana Prestasi Plus.

TABLE III: CORRELATION OF RATING'S METHODS

\begin{tabular}{|c|c|c|c|c|}
\hline & RRn & RS & RMS & RM \\
\hline RRn & 1 & 1 & 0.64422483 & 0.200189218 \\
\hline RS & 1 & 1 & 0.64422483 & 0.200189218 \\
\hline RMS & 0.64422483 & 0.64422483 & 1 & 0.085339627 \\
\hline RM & 0.200189218 & 0.200189218 & 0.085339627 & 1 \\
\hline
\end{tabular}

Source: Data Processing

$R R n=$ Rating based on return

$R S_{R D}=$ Rating based on Sharpe

RMS=Rating based on Modified Snail Trail

$\mathrm{RM}=$ Rating based on Morningstar

TABLE IV: PORTFOLIO BASED ON HIGH RATING EQUITY FUND

\begin{tabular}{|c|c|c|}
\hline \multirow{2}{*}{$\begin{array}{c}\text { Rating based } \\
\text { on Return }\end{array}$} & Expected return & $1.09 \%$ \\
\cline { 2 - 3 } & Standard Deviation & $0.60 \%$ \\
\cline { 2 - 3 } Rating based & Sharpe Index & 1.821549099 \\
\cline { 2 - 3 } on Sharpe & Expected return & $1.09 \%$ \\
\cline { 2 - 3 } & Standard Deviation & $0.60 \%$ \\
\hline \multirow{2}{*}{$\begin{array}{c}\text { Rating based } \\
\text { on Snail Trail }\end{array}$} & Sharpe Index & 1.820609791 \\
\cline { 2 - 3 } & Expected return & $1.00 \%$ \\
\hline Rating based & Standard Deviation & $0.57 \%$ \\
\cline { 2 - 3 } $\begin{array}{c}\text { on } \\
\text { Morningstar }\end{array}$ & Sharpe Index & 1.756889168 \\
\cline { 2 - 3 } & Expected return & $0.67 \%$ \\
\hline Source : Data processing & Sharpe Index & $0.64 \%$ \\
\hline
\end{tabular}

With modified snail trail method, none of Islamic equity funds are granted with 4 and 5 stars.

\section{E. Morningstar Rating}

Using Morningstar Rating method, that averaged the ratings of 3 and 5 years, produces 10 equity funds which granted with 5 and 4 stars. They are Bahana Dana Prima, BNP Paribas Ekuitas, DanareksaMawar, First State IndoequitySectoral Fund, Manulife SahamAndalan, Reksa Dana DanaEkuitas Prima, Schroder Dana Prestasi Plus, Syailendra Equity OpportunityFund, MandiriInvestaAtraktifSyariah, RDTrimSyariahSaham.

The only equity fund that granted 5 stars is BNP Paribas Ekuitas. This is caused by the using of weighted of 3 and 5 years rating performance with rounded in the overall rating, therefore, the amount of high rating equity funds are less than high rating equity funds with other methods.

Under Morningstar Rating method, there are 2 Islamic equity funds which are secured 4 stars rating; they are MandiriInvestaAtraktifSyariahandRD Trim SyariahSaham.

\section{F. Rating Comparison}

After exercising 4 different rating's methods that produce different result for high rating equity funds, correlation between those rating methods will be assessed. The correlation can measured linkage between one rating to another.

Based on the correlation result, can be stated that rating based on return and rating based on Sharpe is perfectly correlated, therefore, these methods produces exactly the same rating method. Less correlation is shown on the rating based on Modified Snail Trail with rating based on the Sharpe with index of 0.644 . These two ratings are showing 18 equal rating out of 36 samples. On the other hand, rating based on Morningstar only produces 12 equal ratings with Sharpe and return, with least correlation index in 0.2 .

TABLE V: BENCHMARK PORTFOLIO USING OPTIMAL ISLAMIC, CONVENTIONAL, AND HYBRID PORTFOLIOS

\begin{tabular}{|c|c|c|c|c|c|c|c|c|}
\hline & \multicolumn{2}{|c|}{$\begin{array}{l}\text { Equallyweight } \\
\text { ed portfolio }\end{array}$} & \multicolumn{2}{|c|}{$\begin{array}{l}\text { Maximizing } \\
\text { return } \\
\text { portfolio } \\
\end{array}$} & \multicolumn{2}{|c|}{$\begin{array}{l}\text { Minimizingrisk } \\
\text { portfolio }\end{array}$} & \multicolumn{2}{|c|}{$\begin{array}{c}\text { Maximize } \\
\text { sharpe ratio } \\
\text { portfolio }\end{array}$} \\
\hline & \multicolumn{2}{|c|}{$\begin{array}{l}36 \text { constituent } \\
\text { equity fund } \\
\text { on the same } \\
\text { weighted. }\end{array}$} & \multicolumn{2}{|c|}{$\begin{array}{c}\text { 100\% Panin } \\
\text { Dana } \\
\text { Maksima }\end{array}$} & \multicolumn{2}{|c|}{$\begin{array}{c}14 \% \text { Reksa } \\
\text { Dana Simas } \\
\text { Danamas } \\
\text { Saham, } 86 \% \\
\text { Schroder Dana } \\
\text { Prestasi Plus }\end{array}$} & \multicolumn{2}{|c|}{$\begin{array}{c}100 \% \text { Panin } \\
\text { Dana } \\
\text { Maksima }\end{array}$} \\
\hline \multirow{3}{*}{ 름 } & $E(R)$ & $0.67 \%$ & $\begin{array}{l}E( \\
R)\end{array}$ & $\begin{array}{l}2.27 \\
\%\end{array}$ & $\begin{array}{l}E(R \\
)\end{array}$ & $0.83 \%$ & $\begin{array}{l}E( \\
R)\end{array}$ & $\begin{array}{l}2.27 \\
\%\end{array}$ \\
\hline & $\Sigma$ & $8.41 \%$ & $\Sigma$ & $\begin{array}{l}8.34 \\
\% \\
\end{array}$ & $\sigma$ & $7.43 \%$ & $\sigma$ & $\begin{array}{l}8.34 \\
\% \\
\end{array}$ \\
\hline & $\mathrm{S}_{\mathrm{RD}}$ & $7.98 \%$ & $\mathrm{~S}_{\mathrm{RD}}$ & $\begin{array}{l}27.21 \\
\%\end{array}$ & $\mathrm{~S}_{\mathrm{RD}}$ & $11.19 \%$ & $\mathrm{~S}_{\mathrm{RD}}$ & $\begin{array}{l}27.21 \\
\% \\
\end{array}$ \\
\hline \multirow{4}{*}{ 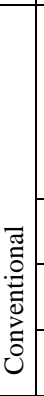 } & \multicolumn{2}{|c|}{$\begin{array}{l}30 \text { constituent } \\
\text { equity fund } \\
\text { on the same } \\
\text { weighted. }\end{array}$} & \multicolumn{2}{|c|}{$\begin{array}{c}\text { 100\% Panin } \\
\text { Dana } \\
\text { Maksima }\end{array}$} & \multicolumn{2}{|c|}{$\begin{array}{c}14 \% \text { Reksa } \\
\text { Dana Simas } \\
\text { Danamas } \\
\text { Saham, 86\% } \\
\text { Schroder Dana } \\
\text { Prestasi Plus } \\
\end{array}$} & \multicolumn{2}{|c|}{$\begin{array}{c}\text { 100\% Panin } \\
\text { Dana } \\
\text { Maksima }\end{array}$} \\
\hline & $\mathrm{E}(\mathrm{R})$ & $0.74 \%$ & $E(R)$ & $\begin{array}{l}2.27 \\
\% \\
\end{array}$ & $E(R)$ & $0.83 \%$ & $E(R)$ & $\begin{array}{l}2.27 \\
\% \\
\end{array}$ \\
\hline & $\Sigma$ & $8.40 \%$ & $\Sigma$ & $\begin{array}{l}8.34 \\
\%\end{array}$ & $\sigma$ & $7.43 \%$ & $\Sigma$ & $\begin{array}{l}8.34 \\
\%\end{array}$ \\
\hline & $\mathrm{S}_{\mathrm{RD}}$ & $8.80 \%$ & & $\begin{array}{l}27.21 \\
\% \\
\end{array}$ & $\mathrm{~S}_{\mathrm{RD}}$ & $11.19 \%$ & $\mathrm{~S}_{\mathrm{RD}}$ & $\begin{array}{l}27.21 \\
\% \\
\end{array}$ \\
\hline \multirow{4}{*}{ 胥 } & \multicolumn{2}{|c|}{$\begin{array}{l}6 \text { constituent } \\
\text { equity funds } \\
\text { on the same } \\
\text { weighted }\end{array}$} & \multicolumn{2}{|c|}{$\begin{array}{c}\text { 100\% Reksa } \\
\text { Dana } \\
\text { Syariah } \\
\text { BNP } \\
\text { Paribas } \\
\text { Pesona } \\
\text { Amanah }\end{array}$} & \multicolumn{2}{|c|}{$\begin{array}{c}\text { 100\% Mandiri } \\
\text { Investa } \\
\text { Atraktif } \\
\text { Syariah }\end{array}$} & \multicolumn{2}{|c|}{$\begin{array}{c}100 \% \text { Reksa } \\
\text { Dana } \\
\text { Syariah } \\
\text { BNP Paribas } \\
\text { Pesona } \\
\text { Amanah }\end{array}$} \\
\hline & $\mathrm{E}(\mathrm{R})$ & $0.31 \%$ & $E(R)$ & $\begin{array}{l}0.86 \\
\%\end{array}$ & $E(R)$ & $0.42 \%$ & $\mathrm{E}(\mathrm{R})$ & $\begin{array}{l}0.86 \\
\%\end{array}$ \\
\hline & $\sigma$ & $8.59 \%$ & $\Sigma$ & $\begin{array}{l}8.46 \\
\%\end{array}$ & $\sigma$ & $7.81 \%$ & $\Sigma$ & $\begin{array}{l}8.46 \\
\%\end{array}$ \\
\hline & $S_{\mathrm{RD}}$ & $3.65 \%$ & $\mathrm{~S}_{\mathrm{RD}}$ & $\begin{array}{l}10.14 \\
\%\end{array}$ & $S_{\mathrm{RD}}$ & $5.39 \%$ & $S_{R D}$ & $\begin{array}{l}10.14 \\
\%\end{array}$ \\
\hline
\end{tabular}

Source: Data Processing

$E(\mathrm{R})=$ Expected Return

$\sigma=$ Standard Deviation

$S_{\mathrm{RD}}=$ Sharpe Index

High Rating Equity Fund Portfolios

Below is the result of high rating equity fund portfolios using back testing method of 5 years.

Based on the result of portfolio, can be concluded that portfolio that consist of high rating equity fund based on return and Sharpe gives the highest expected return and the highest Sharpe Ratio. This result is obvious as rating based on return is sorting the performance based on the return performance given by the equity fund and the high rating equity funds based on return are equity funds with highest return over the 5 years performances, so does high rating 
equity fund based on Sharpe. On the other hand high rating equity fund portfolio based on modified snail trail produces slightly lower expected return than the Sharpe with 3 differences on high rating equity fund's compiler. The lowest expected return and Sharpe ratio is produced by high rating equity fund portfolio that based on Morningstar.

\section{G. Benchmark Portfolio}

The benchmark portfolio used is the optimal Islamic, conventional, and hybrid portfolios that presented with several alternatives, which are equal weight, maximize return, minimize risk, and maximize the Sharpe Index and result can be seen in Table $\mathrm{V}$.

Based on the data processing result, can be stated that high rating equity fund portfolio is outperforming the optimal portfolio for weighted and minimizing risk portfolio for all of three categories. Only in maximizing return and Sharpe ratio, performances of high rating equity fund is underperforming the optimal hybrid, conventional, and Islamic portfolio. The performance mentioned here has already covered the expected return, risk, and Sharpe ratio for each types of portfolio.

\section{CONCLUSION}

This research intends to compare performances of Islamic and conventional equity mutual fund to market which represented by IHSG and JII. The purpose of is research is to examine whether the Islamic mutual fund can outperform the conventional mutual fund and the market.Based on the data processing with ANOVA test in 5\% level of significance, it is found that the return and risk adjusted return performance of Islamic equity funds and market have no significance differences, so do conventional equity funds compared to the market. The return and risk adjusted return performance of Islamic equity funds also have no significance differences.

By using different rating methods, which are return, Sharpe Index, modified snail trail, and Morningstar Rating, this research will assess the rating performance of the samples. The result of rating can be seen on the table 7.8 in the appendixes. The rating based on return and Sharpe Index produce exactly equal rating for each constituent samples. On the other hand, modified snail trail rating produces 18 equal ratings compared to Sharpe, whereas Morningstar rating generate 12 equal ratings.

Based on the rating given by each method, this research constructs portfolios that consist of high rating equity fund for each rating method to assess the accuracy of method to choose the best performance of equity fund. The results of these portfolios are already can be observed. High rating equity fund based on return and Shape Index produces highest return with $1,09 \%$ and Shape Index of $1,82 \%$. The second places is inhabited by high rating equity fund based on modified snail trail with $1 \%$ expected return and $1,75 \%$ Sharpe Index. Benchmark of performance, this research builds optimal Islamic, conventional, and hybrid portfolio with four alternatives. The alternatives are equal weighted portfolio, maximizing return portfolio, minimizing risk portfolio, and maximizing Sharpe Index portfolio. Reposed on the data analyzing, the performance of high rating equity funds, except for Morningstar, are outperforming the Islamic, conventional, and hybrid portfolio in equal weighted portfolio and minimizing risk portfolio.

\section{ACKNOWLEDGEMENT}

We thank to the God who has already gives wisdom to finish this paper. We are grateful for the help of tutors in School of Business and Management, Bandung Institute of Technology for the support.

\section{REFERENCE}

[1] A. Halim. Perkembangan dan prospek perbankan syariah Indonesia: tantangan dalam menyongsong MEA 20151. [Online]. Available: http://www.bi.go.id/NR/rdonlyres/91B56449-C5EA-4B6C-B03E600863889853/25987/PerkembanganProspekPerbankanSyariahIndon esiaMEA201.pdf

[2] Badan Pengawas Pasar Modal dan Lembaga Keuangan, UndangUndang Pasar Modal, no. 8, Bab IV tentang Reksadana,1995.

[3] N. R. Hayati, "Perbandingan kinerja reksa dana pendapatan tetap (konvensional dan syariah) sebagai suatu evaluasi portfolio investor di pasar modal," Journal Bisnis dan Ekonomi, vol. 7, pp. 954-968, 2006.

[4] Badan Pengawas Pasar Modal dan Lembaga Keuangan, Keputusan Ketua Badan Pengawas Pasar Modal dan Lembaga Keuangan tentang Daftar Efek Syariah, 2008.

[5] S. Elfakhani, M. K. Hassan, and Y. Sidani, "Comparative performance of Islamic versus secular mutual funds," working paper, University of New Orleans, 2005.

[6] Musaroh. (2007). Kajian Perbandingan antara Reksa Dana Syariah dan Reksa Dana Konvensional Sebagai Solusi Alternatif Perencanaan Investasi. [Online]. Available: http://staff.uny.ac.id/system/files/penelitian/Musaroh,\%20SE.,M.Si./K AJIAN\%20PERBANDINGAN\%20REKSADANA.pdf

[7] B. K. Marcus, Investment, United States of America: McGraw-Hill, 2003.

[8] T. Y. Keng, "Unit trust performance: the snail trail approach," Pertanika Journal Social Scienceand Humanity, pp. 103-104, 2000.

[9] M. K Dewi and I. R Ferdian, "Evaluating performance of islamic mutual funds in Indonesia and Malaysia," Journal of Applied Economics and Business Research, vol. 2, no. 1, pp. 11-33, 2012.

[10] Morningstar Inc. (2009). The morningstar rating methodology. [Online].

Available: http://corporate.morningstar.com/no/documents/MethodologyDocume nts/MethodologyPapers/MorningstarFundRating_Methodology.pdf.

[11] D. M. Levine, T. C. Krehbiel, and M. L. Berenson, Business Statistics, A First Course, United States of America, Pearson Prentice Hall LTD, 2006.

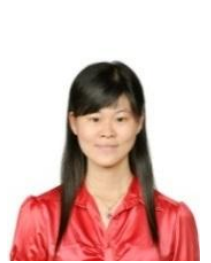

Antonia Febe Hartono was born at Semarang on February $28^{\text {th }}$, 1992. Recently, she has graduated from School of Business and Management, Bandung Institute of Technology, Indonesia in Bachelor of Management majoring in Finance.

She is an active trader in Bursa Efek Indonesia and became a candidate for Chartered Financial Analyst level 1 in June 2013. Her research interest is in corporate finance, valuation, and capital market.

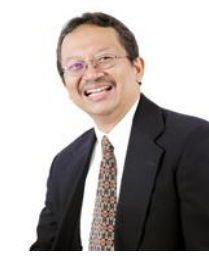

Ir. Subiakto Soekarno is a MBA, RFA, and QWPTM, he was born on Kediri, April $14^{\text {th }}, 1960$. He got an undergraduate degree (Majoring in Mechanical Engineering) from Institute Technology Bandung in 1983. Funded by General Electric Scholarship, he continued his study to the Oklahoma State University -USA in 1992, and got an MBA degree. During his study at the Oklahoma State

University.

He has over 24 years of professional experience in various companies especially in the strategic industry/state owned company and multinational company. During his professional career, he has been 
assigned in various management positions such as: program manager, division general manager, director finance, president commissioner, and chairman of audit committee. His research interest includes but not limited to: Corporate Finance, Valuation, Mergers \& Acquisition, Emerging Markets, and Portfolio Management.

Mr. Soekarno has an extensive personal experience in the capital market area. He has been participating as real investor in Bursa Efek Indonesia, Bursa Berjangka Jakarta, New York Stock Exchange/NASDAQ /CBOE. He earns RFA (Registered Financial Advisor), a financial planner professional title, in 2009, and QWPTM (Qualified Wealth Planner) in 2011.
Sylviana Maya Damayanti is a ST, MBA, RFA, and QWPTM, he was born on Balikpapan, August $13^{\text {th }}$, 1977. She She graduated from MBA ITB with cumlaude and currently works as a full time tutor and researcher for Business Risk and Finance interest group at SBM ITB She earns RFA (Registered Financial Advisor) and QWPTM (Qualified Wealth Planner), a financial planner professional title, in 2009 and 20011.Her research interest areas are in Personal Financial Planning, Financial Analysis, Corporate Finance and Investment Management. 